Gut, 1985, 26, 60-68

\title{
Isolation of intestinal mononuclear cells: factors released which affect lymphocyte viability and function
}

\author{
P R GIBSON, A HERMANOWICZ, H J J VERHAAR, D J P FERGUSON, \\ A LÓPEZ BERNAL, AND D P JEWELL \\ From the Gastroenterology Unit, Radcliffe Infirmary, the Department of Electron Microscopy, John Radcliffe \\ Hospital, and the Nuffield Department of Obstetrics and Gynaecology, John Radcliffe Hospital, Oxford
}

\begin{abstract}
SUMMARY Whether toxic or immunomodulatory factors are released during the collagenase digestion phase of the isolation of mononuclear cells from human intestinal mucosa was investigated by assessing the effect of the collagenase supernatant on the viability and natural killer activity of normal peripheral blood mononuclear cells. Three hours' incubation in collagenase supernatant suppressed natural killer activity by $25 \pm 4 \%$ and decreased the viability of peripheral blood mononuclear cells by $11 \pm 2 \%$. The ability of collagenase supernatants to kill ${ }^{51} \mathrm{Cr}$-labelled peripheral blood mononuclear cells over four hours was assessed in 16 collagenase supernatants, eight of which produced lysis of $20 \pm 4 \%$. There was no ultrastructural evidence of early degenerative changes in the viable intestinal mononuclear cells fresh from the isolation process or in peripheral blood mononuclear cells incubated in collagenase supernatant. Because prostaglandins are known to inhibit natural killer activity, PGE was measured in 20 collagenase supernatants by radioimmunoassay and found to be high at $27.5 \pm 4.0 \mathrm{ng} / \mathrm{ml}$. Addition of indomethacin to the collagenase medium, however, failed to abolish the inhibitory effect of collagenase supernatant on natural killer activity and did not increase the natural killer activity of isolated intestinal mononuclear cells. The release of cytotoxic and immunomodulatory factors during the isolation of intestinal mononuclear cells indicates the necessity for careful assessment of the potential effects of the isolation process on any function being examined and casts doubt upon the relationship between in vitro findings and in vivo functional capabilities.
\end{abstract}

The enzymatic (collagenase) method for isolating mononuclear cells from intestinal mucosa ${ }^{1}$ has been a major advance in the study of local immune mechanisms. It usually yields greater than 2 million cells per gram of mucosa, more than $85-90 \%$ of which are viable. Their survival in culture is similar to mononuclear cells isolated from peripheral blood and they are functionally active. The cells proliferate in response to mitogenic stimuli ${ }^{1-4}$ and mediate lectin-induced cellular cytotoxicity, ${ }_{5} 6$ while $B$ cells synthesise immunoglobulins ${ }^{5} 6$ and macrophages show random motility and chemotaxis similar to peripheral blood monocytes. ${ }^{7}$

A major problem in the interpretation of such functional studies has been the disparity of findings between different investigating groups. For example, the proliferative response of intestinal

Address for correspondence: Dr D P Jewell, Gastroenterology Unit, Radcliffe Infirmary, Oxford OX2 6HE

Received for publication 20 March 1984 mononuclear cells to phytohaemagglutinin is reported to be less than ${ }^{1}$ or equal to ${ }^{4}$ that of autologous peripheral blood mononuclear cells. For Crohn's disease, intestinal mononuclear cells from diseased segments have been reported to respond greater than ${ }^{8}$ or less than ${ }^{3}$ mononuclear cells from histologically normal intestine. Similarly, the pattern of immunoglobulin synthesis differs widely in two reports. ${ }^{56}$ Conflicting results have also been obtained using mechanically-isolated intestinal mononuclear cells in suppressor cell assays ${ }^{9}$ and in their blastogenic response to mitogens ${ }^{10}$ when compared to those using enzymatically-isolated cells. $^{13411}$ Explanations for these observations include differing methodologies for the functional assays and the heterogeneity within the disease groups studied. The possibility that the functional state of the isolated cells may be variably influenced by the enzymatic extraction process, however, has received little attention. Most investigators have 
confirmed that the EDTA and collagenase used in the isolation procedure have minimal effects on the function of peripheral blood mononuclear cells. 3-6 12-14 During the collagenase digestion of the mucosa, however, there is the potential for a release of multiple factors such as proteases and prostaglandins which may profoundly affect the functional status of immunologically active cells.

The aim of this study was to determine if any such immunomodulatory substances are released during the isolation process and the inhibition of natural killer activity was used as a screening test to detect their presence. A factor cytotoxic to peripheral blood mononuclear cells and at least two factors inhibitory to natural killer cells were identified in the supernatant of the collagenase digestion.

\section{Methods}

\section{SPECIMENS}

Intestinal mononuclear cells were isolated by a modification of the method of Bull and Bookman. ${ }^{1}$ Intestinal mucosa was obtained from fresh specimens of intestine surgically resected because of Crohn's disease, ulcerative colitis, colorectal carcinoma, and other diseases (colonic adenomata, peptic ulceration of the colon). The degree of inflammation in Crohn's disease and ulcerative colitis specimens is outlined in the results where appropriate. In patients with carcinoma, the tissue examined was taken distant from the tumour and was histologically normal. None of the noninflammatory bowel disease patients were taking immunologically active drugs whereas all of the Crohn's disease patients and two of four of the ulcerative colitis patients were being treated with high doses of prednisolone (20-64 mg/day). Sulphasalazine had been stopped in all patients before surgery. Heparinised peripheral blood was drawn from normal healthy volunteers.

\section{ISOLATION OF MONONUCLEAR CELLS}

Within one hour of resection, the intestinal mucosa was dissected and minced in approximately $3 \times 3 \mathrm{~mm}$ pieces. Six to eight grams of these were incubated with stirring in Hanks balanced salt solution free of calcium and magnesium (HBSS-CMF) with 0.75 $\mathrm{mM}$ EDTA and $10 \mathrm{mM}$ HEPES buffer for 45 minutes at $37^{\circ} \mathrm{C}$. This was repeated every 30 minutes until no more epithelial cells were seen in the supernatant (usually four to five times). After washing twice with HBSS-CMF, the mucosa now depleted of epithelial cells was incubated with 75-100 ml complete medium (RPMI-1640 with $10 \%$ fetal calf serum, $25 \mathrm{mM}$ HEPES, L-glutamine, 100 $\mu \mathrm{g} / \mathrm{ml}$ streptomycin, and $100 \mathrm{units} / \mathrm{ml}$ penicillin) containing 25 units/ml collagenase (CLSPA, Worthington, Freehold, New Jersey, USA) overnight (approximately 13 , hours) at $37^{\circ} \mathrm{C}$ with stirring. After allowing 20 minutes for the debris to settle, the medium was aspirated and centrifuged at $400 \mathrm{~g}$ for 10 minutes to remove remaining debris and cells. The resulting collagenase supernatant was retained and for most experiments used fresh. Aliquots were also stored at $-20^{\circ} \mathrm{C}$ for future prostaglandin assays and for some mononuclear cells preincubation experiments. Storage at $-20^{\circ} \mathrm{C}$ did not affect the potency of collagenase supernatant to inhibit natural killer activity (data not shown). The cell pellet was washed and resuspended in RPMI-1640 and the mononuclear cells purified over a discontinuous Ficoll-Paque (Pharmacia, Uppsala, Sweden) gradient. After washing twice, the mononuclear cells were resuspended in complete medium. Overt microbial infection was excluded by observation of the $\mathrm{pH}$ of collagenase supernatant, by microscopy of haematoxylin stained preparations of the isolated cells and by prolonged culture of the intestinal mononuclear cells. The supernatants, however, were not routinely cultured.

Heparinised peripheral blood was diluted 1 in 2 with HBSS-CMF and, within two hours of collection, layered onto a discontinuous FicollPaque gradient and centrifuged at $400 \mathrm{~g}$ for 30 minutes. ${ }^{15}$ The peripheral blood mononuclear cells were harvested, washed twice with HBSS-CMF and suspended in complete medium until used. Mononuclear cells were counted using a haemocytometer (Neubauer chamber) and viability determined using $0 \cdot 1 \%$ trypan blue exclusion.

\section{CYTOTOXICITY ASSAYS}

For the natural killer cell assay, K562 cells were used as the target. $0 \cdot 5-1 \times 10^{6} \mathrm{~K} 562$ cells were incubated in $100 \mu \mathrm{l}$ of fetal calf serum and $100 \mu \mathrm{Ci}$ of sodium ${ }^{51}$ chromate (Amersham, Buckinghamshire, England) for one hour at $37^{\circ} \mathrm{C}$. After washing three times, the cells were resuspended in complete medium at a concentration of $1 \times 10^{5}$ cells $/ \mathrm{ml}$. Assays were performed in triplicate or quadruplicate in U-bottomed 96 well microtitre plates (Gibco Bio-Cult, Paisley, Scotland). Fifty microlitres of labelled target cells were added to varying numbers of effector cells according to the effector to target $(\mathrm{E}: \mathrm{T})$ ratio to be used. For peripheral blood mononuclear cells, the E:T ratio was 50:1 and for intestinal mononuclear cells 500:1. Each well was made up to a final volume of $200 \mu \mathrm{l}$ with complete medium. Maximal release was assessed by lysing target cells with Triton-X-100 (BDH Chemicals, Poole, England) in complete 
medium and spontaneous release determined by incubating labelled K562 cells in $200 \mu$ l of complete medium alone. After four hours' incubation at $37^{\circ} \mathrm{C}$ and $5 \% \mathrm{CO}_{2}, 100 \mu \mathrm{l}$ of cell free supernatant was carefully aspirated and counted in a gamma counter.

For the peripheral blood mononuclear cells cytotoxicity assay, $3 \times 10^{6}$ freshly-isolated peripheral blood mononuclear cells depleted of platelets by centrifugation for five minutes at $100 \mathrm{~g}$ were incubated for one hour in $100 \mu \mathrm{l}$ of fetal calf serum and $100 \mu \mathrm{Ci}$ sodium ${ }^{51}$ chromate at $37^{\circ} \mathrm{C}$ followed by washing three times in complete medium. The cells were then incubated a further 30 minutes in $1 \mathrm{ml}$ fetal calf serum then washed once and resuspended in $2-3 \mathrm{ml}$ complete medium. The assay was also performed in U-bottomed 96 well microtitre plates. Fifty microlitres labelled peripheral blood mononuclear cells were added to $150 \mu \mathrm{l}$ of collagenase supernatant (experimental release) or complete medium (spontaneous release). Maximal release was assessed as for the natural killer assay. The time of incubation was four hours at $37^{\circ} \mathrm{C} 5 \% \mathrm{CO}_{2}$ and the supernatant was harvested and counted similarly to the natural killer assay. Centrifugation before harvesting was found to be unnecessary.

For all assays, the average of triplicate or quadruplicate wells was taken and the cytotoxocity determined by the following formula: $\%$ lysis = $(\mathrm{E}-\mathrm{S}) /(\mathrm{M}-\mathrm{S}) \times 100$, where $\mathrm{E}=$ experimental release, $\mathrm{S}=$ spontaneous release, and $\mathrm{M}=$ maximal release. Spontaneous release for K562 cells was $5-10 \%$ and for peripheral blood mononuclear cells $7-20 \%$ of maximum.

\section{INDIRECT IMMUNOFLUORESCENCE}

Natural killer cell proportions were measured in peripheral blood mononuclear cells suspensions by indirect immunofluorescence techniques previously described ${ }^{16}$ using the monoclonal antibody, antiLeu-7(HNK-1) $)^{19}$ (Becton Dickinson, Mountain View, California, USA). Goat-anti-mouse IgM conjugated to tetramethylrhodamine isothiocyanate (Nordic, Tilburg, The Netherlands) was used as the second layer in a concentration of 1 in 10 . As control, an IgM antibody to granulocytes was used in place of the first antibody. The resulting smears were examined by fluorescent and phase microscopy and at least 200 mononuclear cells were counted.

\section{ELECTRON MICROSCOPY}

The cell suspensions were fixed in $4 \%$ glutaraldehyde in phosphate buffer $\mathrm{pH} 7.2$ for a minimum of four hours. Pellets were formed by centrifugation and were post fixed in $2 \%$ osmium tetroxide for two hours before dehydration in ethanol and embedded in Spurr's low viscosity epon. Sections were stained with uranyl acetate and lead citrate before examination in a Philips 301 electron microscope.

The ruthenium red staining was carried out as described by Luft $^{18}$ with $0.15 \%$ ruthenium red present in both the primary and post fixatives. The thin sections in this case were examined unstained.

PROSTAGLANDIN ASSAY

Prostaglandin concentrations in collagenase supernatant were measured by radioimmunoassay. A rabbit antiserum obtained by Dr S P Brennecke (Nuffield Department of Obstetrics and Gynaecology, Oxford) was used. The specificity of this antiserum was tested against a large series of prostaglandins and their metabolites. The only significant cross-reactants were: prostaglandin $\mathrm{E}_{2}$ $\left(\mathrm{PGE}_{2}\right) 100 \%, \mathrm{PGE}_{1} 100 \%$, PGA $18 \%$, 6-oxo PGE $7 \%$, 13,14-dihydro $\mathrm{PGE}_{1} 6 \%, \mathrm{PGA}_{2} 3 \%, \mathrm{PGF}_{2 \mathrm{a}}$ 2\%, 13,14-dihydro $\mathrm{PGE}_{2}$ and $\mathrm{PGF}_{1 \mathrm{a}} 1 \%$. The results were expressed as $\mathrm{PGE}$ as the antiserum does not distinguish between $\mathrm{PGE}_{1}$ and $\mathrm{PGE}_{2}$.

The assay was performed directly on collagenase supernatant without an extraction step. Samples of collagenase supernatant were diluted $1 / 20$ to $1 / 80$ with potassium phosphate buffered saline $(0.1 \mathrm{M}$, $\mathrm{pH} 7.4)$ and incubated in duplicate $(0.1 \mathrm{ml})$ with 0.1 ml antiserum (final dilution 1/2250) and $0.1 \mathrm{ml}$ buffer containing $6 \mu \mathrm{Ci}\left[{ }^{3} \mathrm{H}\right] \mathrm{PGE}_{2}$ (SA $160 \mathrm{Ci} /$ mmol; Amersham, Buckinghamshire, England). Tubes containing known amounts of $\mathrm{PGE}_{2}(0-200$ $\mathrm{pg}$ ) were incubated in parallel. After incubation, free and bound prostaglandins were separated by adding $1 \mathrm{ml}$ of a $1.25 \%$ charcoal $-0.125 \%$ dextran 75 suspension and centrifuging at $3000 \mathrm{~g}$ for 10 minutes. The radioactivity of the supernatant was measured by liquid scintillation counting. The intraassay coefficient of variation was $7 \%$. Blanks of buffer alone or complete medium (diluted 1/4 with buffer) were indistinguishable from zero. PGE levels were undetectable in complete medium at the same dilutions as that of the samples of collagenase supernatant.

\section{STATISTICS}

Data have been expressed as mean \pm standard error and were compared using Wilcoxon's rank sum test or Student's $t$ test.

\section{Results}

EFFECT OF PREINCUBATION OF PERIPHERAL BLOOD MONONUCLEAR CELLS WITH COLLAGENASE SUPERNATANT ON NATURAL KILLER ACTIVITY $5-10 \times 10^{6}$ normal peripheral blood mononuclear cells were incubated in $5-10 \mathrm{ml}$ collagenase supernatant for three hours at $37^{\circ} \mathrm{C}$. As a control, a 
similar number of peripheral blood mononuclear cells were incubated in parallel in complete medium alone. The cells were then washed twice and resuspended in complete medium and, within three hours, tested for their natural killer activity against K562 target cells. In 35 studies, the natural killer activity decreased from $43 \pm 3 \%$ to $31 \pm 3 \%$ without alteration in the proportion of cells with the natural killer $\left(\mathrm{Leu}-7^{+}\right)$phenotype $(9.0 \pm 3.6 \%$ compared with $9 \cdot 1 \pm 4 \cdot 2 \%)$. The percentage decrease of cytotoxicity, as presented in Figure 1, was similar for collagenase supernatant from inflamed intestine of patients with Crohn's disease or ulcerative colitis and from histologically normal mucosa. Filtration of collagenase supernatant through $0.22 \mu \mathrm{m}$ filters (Millipore) did not change the observed suppression of natural killer activity of preincubated peripheral blood mononuclear cells.

\section{CYTOTOXICITY OF COLLAGENASE SUPERNATANT}

TO PERIPHERAL BLOOD MONONUCLEAR CELLS

Three hours' incubation of peripheral blood mononuclear cells in collagenase supernatant decreased the total mononuclear cells count from $8.5 \pm 1.2 \times 10^{6}$ to $6 \cdot 1 \pm 0.8 \times 10^{6}$ and the viability by $11 \pm 2 \%$ compared with cells incubated in complete medium alone suggesting the presence of a cytotoxic factor (Fig. 2). Supernatants from specimens showing histological inflammation affected viability to the same degree as those from histologically normal intestine $(12.3 \pm 2.7 \%, 9 \cdot 4 \pm 2 \cdot 6 \%, \mathrm{p}>0 \cdot 1)$.

Sixteen collagenase supernatants were assessed for their ability to kill ${ }^{51} \mathrm{Cr}$-labelled peripheral blood mononuclear cells by incubating the mononuclear cells in an $80 \%$ concentration of collagenase supernatant for four hours. Seven produced no cytolysis while, in the other nine, cytotoxicity of $20 \pm 4 \%$ was seen. In two experiments, collagenase alone in culture medium produced no cytotoxicity. As detailed in Table 1, the detection of cytotoxins in the collagenase supernatant tended to be associated with a lower than expected intestinal mononuclear cells yield, was more commonly produced from histologically normal tissue (seven of 10 ) than from inflamed mucosa (two of six), but was not associated with a lower viability of the isolated intestinal mononuclear cells. The ability of collagenase supernatant to inhibit the natural killer activity of preincubated peripheral blood mononuclear cells appeared to be independent of the presence of mononuclear cell cytotoxins (Table 1). The natural killer activity of the isolated intestinal mononuclear cells was tested in 10 of the 12 patients. In all, it was less than $6 \%$, being less than $2 \%$ in seven.

The effect of filtering collagenase supernatant through $0.22 \mu \mathrm{m}$ filters was assessed in seven

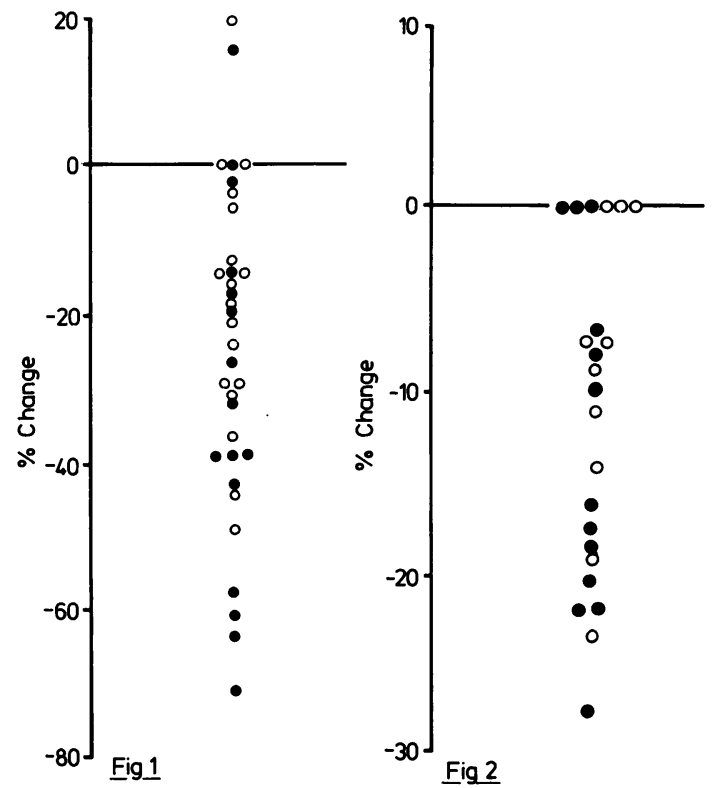

Fig. 1 Effect of collagenase supernatant on natural killer activity of normal peripheral blood mononuclear cells. Peripheral blood mononuclear cells were incubated in collagenase supernatant for 3 hours, washed twice and tested for natural killer activity within 3 hours. Inflamed mucosa (O) was taken from patients with Crohn's disease or ulcerative colitis whereas mucosa that showed no histological abnormality $(O)$ derived from patients with colorectal carcinoma, other non-inflammatory bowel disease, or from uninvolved segments of intestine of patients with Crohn's disease and ulcerative colitis.

Fig. 2 Effect of collagenase supernatant on viability (trypan blue exclusion) of normal peripheral blood mononuclear cells preincubated in collagenase supernatant for three hours. The results are divided according to the presence $(\Theta)$ or absence $(O)$ of inflammation histologically in the intestinal specimens. The viability of control mononuclear cells preincubated in complete medium only was always greater than $95 \%$.

supernatants exhibiting $25 \pm 4 \%$ cytotoxicity. Filtering abolished the cytotoxicity in all studies. In two additional experiments, filtration through $5 \mu \mathrm{m}$ filters also abolished cytotoxicity.

\section{ELECTRON MICROSCOPY}

The morphology of freshly isolated intestinal mononuclear cells and of normal peripheral blood mononuclear cells incubated in collagenase supernatant for three hours was assessed by transmission electron microscopy. There were numerous mononuclear cells present in both cases as well as a number of degenerative cells and cell 
Table 1 The relationship of the cytotoxic and NK-suppressive effects of collagenase supernatant to mucosal histology and to intestinal MNC yield and viability.

\begin{tabular}{|c|c|c|c|c|c|c|c|}
\hline \multirow{3}{*}{$\begin{array}{l}\text { Patient } \\
\text { number }\end{array}$} & \multirow[b]{3}{*}{ Disease } & \multirow[b]{3}{*}{ Tissue } & \multirow[b]{3}{*}{ Histology } & \multirow{2}{*}{\multicolumn{2}{|c|}{ Intestinal MNC }} & \multicolumn{2}{|c|}{ Collagenase supernantant } \\
\hline & & & & & & \multirow{2}{*}{$\begin{array}{l}\text { Cytotoxicity } \\
\text { to PBMNC* }\end{array}$} & \multirow{2}{*}{$\begin{array}{l}\text { Suppression of } \\
\text { NK activity (\%) }\end{array}$} \\
\hline & & & & Yield $\left(\times 10^{6} / \mathrm{g}\right)$ & Viability (\%) & & \\
\hline 1 & Carcinoma & Colon & Normal & $2 \cdot 0$ & 93 & 30 & 33 \\
\hline 2 & Carcinoma & Colon & Normal & $2 \cdot 0$ & 93 & 31 & 30 \\
\hline 3 & Crohn's disease & Ileum & Inflamed & $1 \cdot 6$ & 90 & 39 & NT \\
\hline \multirow[t]{2}{*}{4} & Crohn's disease & Ileum & Normal & $5 \cdot 0$ & 92 & 0 & NT \\
\hline & & Colon & Inflamed & $10 \cdot 0$ & 90 & 0 & NT \\
\hline 5 & Ulcerative colitis & Colon & Inflamed & $14 \cdot 5$ & 85 & 0 & 39 \\
\hline 6 & Carcinoma & Colon & Normal & $1 \cdot 0$ & 85 & 16 & NT \\
\hline \multirow[t]{2}{*}{7} & Carcinoma & Ileum & Normai & $8 \cdot 0$ & 91 & 10 & 30 \\
\hline & & Colon & Normal & $6 \cdot 2$ & 94 & 7 & 37 \\
\hline 8 & Ulcerative colitis & Colon & Inflamed & $49 \cdot 0$ & 92 & 0 & 61 \\
\hline 9 & Crohn's disease & Ileum & Inflamed & $10 \cdot 0$ & 97 & 0 & 39 \\
\hline 10 & Carcinoma & Colon & Normal & $1 \cdot 5$ & 90 & 26 & 15 \\
\hline 11 & Carcinoma & Colon & Normal & $4 \cdot 0$ & 95 & 0 & 50 \\
\hline 12 & Crohn's disease & Colon & Inflamed & $10 \cdot 0$ & 92 & 8 & 0 \\
\hline
\end{tabular}

* Cytotoxicity of ${ }^{51} \mathrm{Cr}$-labelled PBMNC incubated for four hours in CS.

$\ddagger$ Normal PBMNC preincubated in CS for three hours, washed, then tested for NK activity within three hours. Control NK activity was always greater than $20 \%$.

NT = not tested. $\quad$ MNC $=$ mononuclear cells. $\quad$ PBMNC $=$ peripheral blood mononuclear cells.

$\mathrm{NK}=$ natural killer. $\mathrm{CS}=$ collagenase supernatants.

debris which appeared to be phagocytosed by macrophages (Fig. 3). The majority of mononuclear cells appeared viable with normal ultrastructural appearances and exhibited none of the features associated with the early stages of cell death by either apoptosis or coagulative necrosis ${ }^{19}$ (Fig. 4). In addition, the physiological intact nature of the plasmalemma was confirmed by the exclusion of the ruthenium red (Fig. 5).

\section{RELEASE OF PROSTAGLANDINS AND THE EFFECT}

OF IN DOMETHACIN

The mean concentration of PGE in 20 collagenase supernatants was $27.5 \pm 4.0 \mathrm{ng} / \mathrm{ml}$ as measured by radioimmunoassay. Significantly more PGE tended to be released from inflamed $(38.1 \pm 6.3 \mathrm{ng} / \mathrm{ml})$ compared with non-inflamed tissue $(19.0 \pm 11.9 \mathrm{ng} /$ $\mathrm{ml}, \mathrm{p}<0.05)$. To inhibit the synthesis of prostaglandins, $10^{-6} \mathrm{M}$ indomethacin was added to the collagenase-containing medium before the mucosal digestion. This did not affect the intestinal cell yield (data not shown) but did markedly decrease the PGE concentration in the collagenase supernatant (Table 2) to concentrations far below those capable of suppressing natural killer activity in two experiments and to a level at which PGEmediated inhibition is just detectable in the third. ${ }^{20}$ The indomethacin treatment, however, failed to abolish the inhibitory effect of collagenase supernatant on natural killer activity of preincubated peripheral blood mononuclear cells and the natural killer activity of the isolated intestinal mononuclear cells did not change (Table 2).

\section{Discussion}

This study shows that factors influencing the viability and natural killer activity of peripheral

Table 2 Effect of indomethacin on prostaglandin $E$ concentration in and the suppression of NK activity by collagenase supernatants from three patients.

\begin{tabular}{lccc}
\hline & Patient 1 & Patient 2 & Patient 3 \\
\hline PGE concentration of CS (ng/ml) & & & \\
without indomethacin & 32 & 25 & 18 \\
with indomethacin & $0 \cdot 16$ & $0 \cdot 18$ & 5 \\
Incubation of normal PBMNC in CS $(\%$ change NK activity)* \\
without indomethacin & -39 & -2 & -33 \\
with indomethacin $\dagger$ & -20 & 0 & -12 \\
NK activity of patients' intestinal MNC (\%) & & \\
without indomethacin & $<2$ & 5 & $<2$ \\
with indomethacin & $<2$ & 7 & $<2$ \\
\hline
\end{tabular}

* NK activity of normal PBMNC used in assessing CS from patients 1,2 , and 3 was $35 \%, 49 \%$, and $18 \%$ respectively.

+ Experimental values compared with control studies using culture medium containing $10^{-6} \mathrm{M}$ indomethacin. 


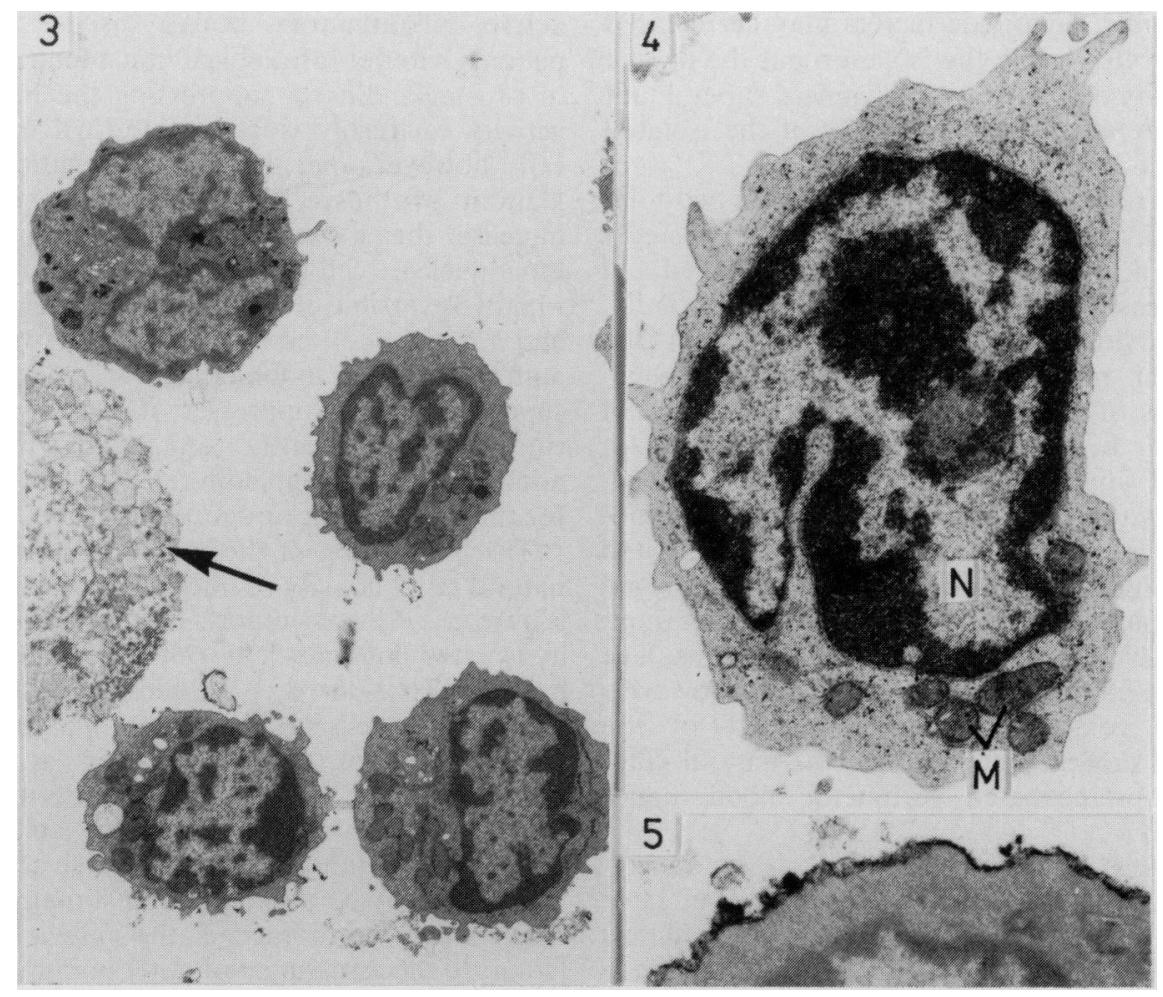

Figs. 3-5 Electron micrographs of isolated intestinal cells. (3) Low power showing four normal appearing lymphocytes and part of a dead cell (arrow). ( $\times 5600$ original magnification). (4) Lymphocyte with normal nuclear and cytoplasmic morphology. N-nucleus, M-mitochondria (×13 000 original magnification). (5) Part of a lymphocyte from a sample treated with ruthenium red. Note that the ruthenium red staining is limited to the exterior of the cell. $(\times 20000$ original magnification).

blood mononuclear cells are released during the phase of collagenase digestion in the isolation of mononuclear cells from human intestinal mucosa. Assay of natural killer activity was used to screen for possible immunomodulatory substances for two reasons. Firstly, as the cytolysis of the highly sensitive target cell, K562, occurs rapidly (mostly within one to two hours) ${ }^{21}$ the cytotoxicity determined should be a true reflection of the functional status of the natural killer cell fresh from the isolation process. Recovery of the cells during prolonged culture would be minimised. Secondly, the natural killer cell is sensitive to multiple in vitro modulating influences ${ }^{22}$ and therefore provides an ideal target for the detection of such factors.

The demonstration that collagenase supernatants are cytotoxic to peripheral blood mononuclear cells is not surprising. Substances causing cytopathic effects to monolayer cell culture are found in intestinal mucosal homogenates ${ }^{23-25}$ and some of these have been partly characterised. ${ }^{25}$ The cytotoxic factor in collagenase supernatant, however, was not ultrafiltrable. This suggests the possibility that bacterial contamination of the collagenase supernatant may have been a contributing factor but prolonged cultures and stained preparations of the isolated intestinal cells revealed no evidence for the presence of any bacteria though direct cultures of the collagenase supernatant were not performed. In addition, bacteria were never observed in any sample examined ultrastructurally. Alternatively, particulate matter, of which there are large amounts in collagenase supernatant, may be exerting a nonspecific effect. To support this, filtration through 5 $\mu \mathrm{m}$ filters in two experiments also abolished cytotoxic activity. It is also possible that soluble toxins may be adsorbed onto particulate matter or even adsorbed onto the filter. Thus, the nature of the toxin remains unclear. The collagenase itself is 
not responsible. Cytotoxic factors may be released from dying cells during the isolation but the degree of cytotoxicity exhibited by collagenase supernatant did not correlate with the viability of the isolated intestinal cell population.

The importance of the cytotoxic factor is two-fold. Firstly, it may offer an explanation for unexpectedly low yields of mononuclear cells from inflamed and normal mucosa which occasionally occur. Secondly, it may provide one mechanism by which the functions of mononuclear cells are suppressed. Specific loss of the natural killer $\left(\mathrm{Leu}-7^{+}\right)$cell of peripheral blood during preincubation in collagenase supernatant did not occur. No ultrastructural evidence that the viable intestinal mononuclear cells or collagenase supernatant-treated peripheral blood mononuclear cells are damaged could be found but this does not exclude a nonspecific toxic effect on some of their functions. The detection of mononuclear cell cytotoxins, however, bore little relationship to the ability of the collagenase supernatant to inhibit the natural killer activity of preincubated peripheral blood mononuclear cells.

The natural killer suppressive effect of collagenase supernatant acted upon the effector population as in none of the reported experiments was the target cell exposed to collagenase supernatant. Addition of dilutions of collagenase supernatant directly to the natural killer assay also inhibit natural killer activity but the complex cytotoxic and modulating effects on both effector and target cells made interpretation difficult (data not shown).

The factors suppressing natural killer activity appear to be present in the soluble fraction of collagenase supernatant. Previous studies by us ${ }^{14}$ and others ${ }^{12}{ }^{13}$ have shown that collagenase itself is not responsible. Prostaglandins are widely distributed in tissues and are actively produced by many cells including lymphocytes and macrophages. They have multiple effects on immunological functions and prostaglandins of the $E$ series are potent inhibitors of natural killer function. ${ }^{2026-28}$ It has been previously shown that prostaglandins are released during the mechanical method of isolating intestinal mononuclear cells and that these influenced the measurement of antibody-dependent cellular cytotoxicity. ${ }^{29}$ The present study has shown that during the collagenase digestion of intestinal mucosa, concentrations of PGE which have previously been shown to inhibit natural killer activity $^{20}$ are also produced from both normal as well as inflamed tissue. As might be expected from a recent study, ${ }^{30}$ greater concentrations of PGE tended to be released from mucosa of patients with active inflammatory bowel disease than from patients without histological inflammation. The role of prostaglandins in suppressing the natural killer activity of freshly isolated intestinal mononuclear cells, however, appears small as inhibition of prostaglandin synthesis with indomethacin failed to increase the natural killer activity of intestinal mononuclear cells. PGE has a short-lived and rapidly-reversible effect on natural killer activity ${ }^{26} 28$ and a major suppressive contribution would not be anticipated. The indomethacin-treated collagenase supernatant still suppressed natural killer activity though less potently, suggesting that factors additional to prostaglandin release were responsible for the suppression of natural killer activity.

The implication of these findings to the study of natural killer activity of intestinal mononuclear cells is obvious. Previous reports of low or absent activity in isolated mononuclear cells populations ${ }^{4} 121331$ has been considered to be because of a paucity of natural killer cells within the intestinal mucosa. ${ }^{14}$ As these cells are exposed during an overnight incubation to factors which potently inhibit peripheral blood natural killer cell function, however, the intestinal natural killer activity being measured may be a gross underestimate.

Of wider importance is the relevance of such factors to the assessment of other immune functions. Whether the effects of collagenase supernatant on natural killer activity are reversible was not determined but the effect of more than 10 hours' incubation of intestinal mononuclear cells in a medium containing such potent toxic and modulating factors must result in the isolation of mononuclear cells with functional capabilities distant from those in vivo. In addition, the influences of collagenase supernatant appear to be unpredictable and independent of underlying mucosal histology. Thus, studies of enzymatically isolated intestinal mononuclear cells are unlikely to yield quantitative information of sufficient accuracy to allow assessment of subtle disease related differences unless such methodological problems can be overcome. This may possibly be achieved by manipulation of the isolation technique or by allowing sufficient time in culture for the cells to recover before subjecting them to in vitro functional assay.

In conclusion, a mononuclear cell cytotoxin, PGE, and other natural killer inhibitory factors are released during the collagenase digestion of human intestinal mucosa. The major implication of these findings is that any in vitro functional assay of intestinal mononuclear cells must be carefully interpreted in the light of the possible artefactual influences the isolation process may have on that 
function. They also cast doubt upon the relationship of in vitro intestinal cell function to in vivo activity when enzymatically isolated mononuclear cells are studied.

Anti-Leu-7(HNK-1) antibody was generously donated by Dr N Warner of the Becton Dickinson Monoclonal Antibody Centre, Mountain View, California. PRG was in receipt of a grant from the Oxfordshire Regional Health Authority. AH, from the Gastroenterology Department, Silesian School of Medicine, Katowice, Poland, was supported by the Wellcome Trust.

\section{References}

1 Bull DM, Bookman MA. Isolation and functional characterization of human intestinal mucosal lymphoid cells. J Clin Invest 1977; 59: 966-74.

2 Fiocchi C, Battisto JR, Farmer RG. Gut mucosal lymphocytes in inflammatory bowel disease. Isolation and preliminary functional characterization. Dig Dis Sci 1979; 24: 705-17.

3 MacDermott RP, Bragdon MJ, Jenkins KM, Franklin GO, Shedlofsky S, Kodner IJ. Human intestinal mononuclear cells. II. Demonstration of a naturally occurring subclass of $T$ cells which respond in the allogenic mixed leukocyte reaction but do not effect cell-mediated lympholysis. J Immunol 1981; 80: 748-57.

4 Bland PW, Britton DC, Richens ER, Pledger JV. Peripheral, mucosal, and tumour-infiltrating components of cellular immunity in cancer of the large bowel. Gastroenterology 1981; 22: 744-51.

5 Bookman MA, Bull DM. Characteristics of isolated intestinal mucosal lymphoid cells in inflammatory bowel disease. Gastroenterology 1979; 77: 503-10.

6 MacDermott RP, Nash GS, Bertovich MJ, Seiden MV, Bragdon MJ, Beale MG. Alterations of IgM, IgG, and IgA synthesis and secretion by peripheral blood and intestinal mononuclear cells from patients with ulcerative colitis and Crohn's disease. Gastroenterology 1981; 81: 844-52.

7 Gibson PR, Hermanowicz A, Pallone F, Jewell DP. Motility of intestinal mononuclear cells in inflammatory bowel disease. [Abstract] Gut 1984; 25: A567-8.

8 Machado I, Falchuk ZM. Lamina propria lymphocytes: differing responses to mitogenic stimulation between inflammatory bowel disease and other diseases. Gastroenterology 1978; 74: A1059.

9 Goodacre R, Bienenstock J. Loss of suppressor cell activity in intestinal lymphocytes from patients with Crohn's disease. Gastroenterology 1982; 82: 653-8.

10 Goodacre R, Davidson R, Singal D, Bienenstock J. Morphologic and functional characteristics of human intestinal lymphoid cells isolated by a mechanical technique. Gastroenterology 1979; 76: 300-8.
11 Fiocchi C, Youngman KR, Farmer RG. Immunoregulatory function of human intestinal mucosa lymphoid cells: evidence for enhanced suppressor cell activity in inflammatory bowel disease. Gut 1983; 24: 692-701.

12 MacDermott RP, Franklin GO, Jenkins KM, Kodner IJ, Nash GS, Weinrieb IJ. Human intestinal mononuclear cells. I. Investigation of antibodydependent, lectin-induced, and spontaneous cellmediated cytotoxic capabilities. Gastroenterology 1980; 78: 47-56.

13 Falchuk ZM, Barnhard E, Machado I. Human mononuclear cells: studies of cytotoxic function. Gut 1981; 22: 290-4.

14 Gibson PR, Dow EL, Selby WS, Strickland RS, Jewell DP. Natural killer cells and spontaneous cell-mediated cytotoxicity in the human intestine. Clin Exp Immunol 1984; 56: 438-44.

15 Boyum A. Separation of leukocytes from blood and bone marrow. Scand J Clin Lab Invest 1968; 21: 31-50.

16 Selby WS, Jewell DP. T lymphocyte subsets in inflammatory bowel disease: peripheral blood. Gut 1983; 24: 99-105.

17 Abo T, Balch CM. A differentiation antigen of human NK and $\mathrm{K}$ cells identified by a monoclonal antibody. $J$ Immunol 1981; 127: 1024-9.

18 Luft JH. Ruthenium red and violet. 1. Chemistry, purification, methods of use for electron microscopy and mechanism of action. Anat Rec 1971; 171: 347-68.

19 Wyllie AH, Kerr JFR, Currie AA. Cell death: the significance of apoptosis. Int Rev Cytol 1980; 68: 251-306.

20 Hall TJ, Chen S-H, Brostoff J, Lydyard PM. Modulation of human natural killer cell activity by pharmacological mediators. Clin Exp Immunol 1983; 54: 493-500.

21 Callewaert DM. Quantitation of human natural and antibody-dependent cytotoxicity. In: Herberman RB, ed. Natural cell-mediated immunity against tumours. New York: Academic Press, 295-305.

22 Roder JC, Karre K, Kiessling R. Natural killer cells. Prog Allergy 1981; 28: 66-159.

23 Phillpotts RJ, Hermon-Taylor J, Brooke BN. Virus isolation studies in Crohn's disease. Gut 1979; 20: $1057-62$.

24 Morain CO, Prestage H, Harrison P, Levi AJ, Tyrell DA. Cytopathic effects in cultures inoculated with material from Crohn's disease. Gut 1981; 22: 823-6.

25 McLaren LC, Gitnick G. Ulcerative colitis and Crohn's disease tissue cytotoxins. Gastroenterology 1982; 82: 1381-8.

Roder JC, Klein M. Target-effector interaction in the natural killer cell system. IV. Modulation by cyclic nucleotides. J Immunol 1979; 123: 2785-9.

27 Brunda MJ, Herberman RB, Holden HT. Inhibition of murine natural killer activity by prostaglandins. $J$ Immunol 1980; 124: 2682-7.

28 Lang NP, Ortaldo JR, Bonnard GD, Herberman RB. Interferon and prostaglandins: effects on human natural and lectin-induced cytotoxicity. $J$ Natl Cancer Inst 1982; 69: 339-43.

29 Bland PW, Richens ER, Britton DC, Lloyd JV. 
Isolation and purification of human large bowel mucosal lymphoid cells: effect of separation technique on functional characteristics. Gut 1979; 20: 1037-46.

30 Zifroni A, Treves AJ, Sachar DB, Rachmilewitz D. Prostanoid synthesis by cultured intestinal epithelial and mononuclear cells in inflammatory bowel disease.
Gut 1983; 24: 659-64.

31 Chiba M, Bartnick W, ReMine SG, Thayer WR, Shorter RG. Human colonic intraepithelial and lamina propria lymphocytes: cytotoxicity in vitro and the potential effects of the isolation method on their functional properties. Gut 1981; 22: 177-86.

\section{Forthcoming Scientific Meetings of the British Society of Gastroenterology}

Brighton 20-22 March 1985

Newcastle-upon-Tyne 18-20 September 1985

Lancaster 9-11 April 1986

Cardiff 24-26 September 1986

London 15-18 September 1987

For details of registration please contact: The Administrative Secretary, British Society of Gastroenterology, Rayne Institute, 5 University Street, London, WC1E 66JJ. Tel: (44: country code) 01-387-3534. 